\title{
Exchange rate changes, price level and the income effects on trade balance in South Africa
}

\section{Eliphas Ndou ${ }^{1}$}

Received: 10 October 2020 / Accepted: 9 January 2021 / Published online: 1 February 2021

(c) The Author(s), under exclusive licence to Springer Nature Switzerland AG part of Springer Nature 2021

\begin{abstract}
This paper examines the long-run and short-run effects of the exchange rate changes on the net trade balance in South Africa and compares the effects to those induced by the foreign and domestic price and income effects. Using annual data from 1970 to 2019 and the autoregressive distributed lags bounds testing approach, evidence shows that the long-run elasticities of the exchange rate on the net trade balance are bigger than the short-run impacts. In both the short run and long run, the impact of domestic income on the net trade balance is the biggest followed by consumer prices and then last is the nominal effective exchange rate. The long-run impact of the domestic income is nearly double that of the exchange rate. This shows that domestic income has a bigger effect on the net trade balance than both the price levels and the exchange rate effects. These results imply that policymakers designing the exchange rate policy should complement this with an appropriate industrial policy which emphasises the value of import-substituting industries to eliminate the net trade deterioration. At the same time, the design of the inflation targeting framework matters. Hence, there is a need to pursue import-substitution strategies to strengthen the domestic industrial base with all the associated multiplier effects throughout the economy and this contributes to the reduction of the worsening trade deficits.
\end{abstract}

Keywords Time series · Exchange rate elasticity · Income elasticity · Autoregressive distributed lag model

JEL Classification C32 $\cdot$ C22 $\cdot$ F14

Eliphas Ndou

eliphasndou@yahoo.com

1 University of the Witwatersrand, Johannesburg, South Africa 


\section{Introduction}

Post-2009, saw a combination of factors which included sovereign credit rating downgrades, the COVID-19 pandemic outbreak and the complete lockdown of the economy to contain the spread of the COVID-19 virus, which lead the daily rand to US dollar (R/US\$) exchange rate exceed the R19/US\$ level in 2020. Such a level of the rand to US dollar exchange rate depreciation has not been seen in a long time. The global economy also went into a shut-down and this has affected global trade and economic activity. This resulted in the United States (US) and the Euro area economies recording negative real GDP growth rates in the first quarter of 2020. According to the South African Reserve Bank (SARB) and other sources of economic forecasts, the domestic economy is expected to contract by more than $4 \%$ in 2020 and inflation is projected to be lower than $6 \%$.

The concurrence of weak global and domestic growth, alongside dissipating global and domestic inflationary pressures, and the domestic exchange rate depreciation, motivates me to investigate the short-run and long-run effects of the determinants of the net trade balance. What are the long-run and short-run effects of the nominal effective exchange rate changes on the net trade balance in South Africa? How do the effects of the exchange rate on the net trade balance compare to those induced by foreign and domestic prices and income effects in South Africa?

It is important to briefly state the South African Central Bank adopted the inflation targeting policy framework in February 2000. Monetary policymakers target the headline consumer price inflation and the inflation target band is set at 3-6\%. In addition to the adoption of the inflation targeting policy framework, the country has a floating exchange rate policy. Both the price stability mandate and the floating exchange rate can help to maintain the external competitiveness. The analysis in this paper matters because it shows the various channels through which the trade balance can be improved. The findings from these questions can be used in the design of the exchange rate policy, inflation policy and industrial policy regarding the import-substitution strategies, as there is call for structural economic reforms which include industrial policy.

International economic theory suggests that a weaker currency should make domestic exports cheaper, thereby raising the net trade balance, ceteris paribus. In addition, increases in foreign incomes are expected to raise the demand for domestic goods, leading to improvements in the net trade balance, ceteris paribus. The increase in domestic income is predicted to raise the consumption of imports which is expected to lead to the deterioration of the net trade balance, ceteris paribus. Furthermore, cheaper foreign prices are expected to raise demand for imports which will worsen the deterioration in the net trade balance. By contrast, cheaper domestic prices are expected to raise exports volumes thereby raising the net trade surplus. These theoretical predictions indicate that there are opposing effects, which is why it is important to investigate the size of their effects on the net trade balance. Furthermore, it is unknown whether it is the short-run effects that have a bigger influence on the net trade balance compared to the long-run impacts. 

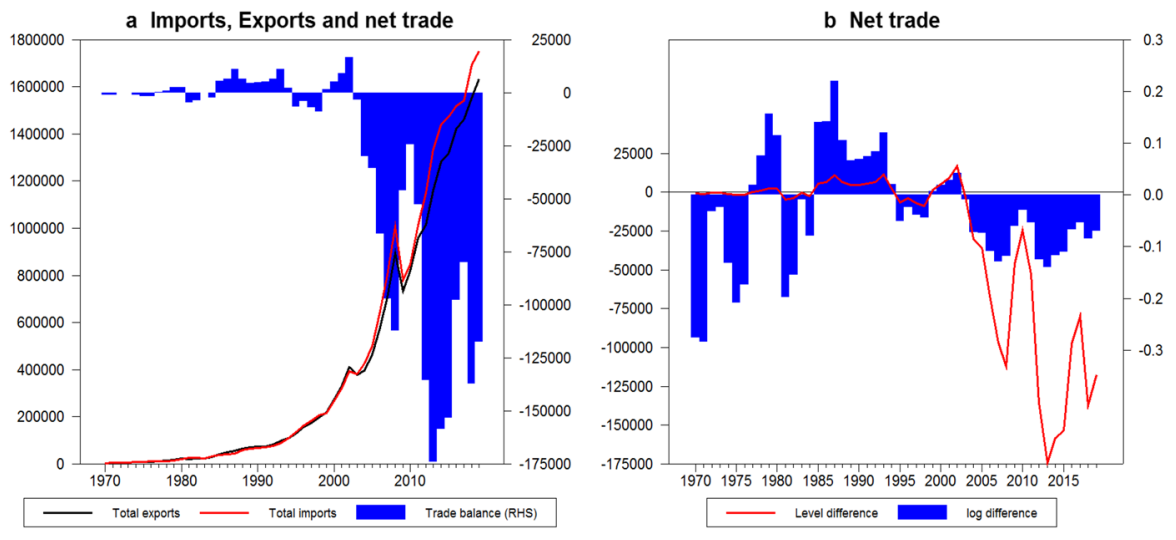

Fig. 1 Annual total imports of goods and services, exports of goods and services and the net trade balance in millions of Rands. Source: SARB and own calculations

As shown in Fig. 1, annual total imports of goods and services have persistently exceeded total exports of goods and services since 2001. This indicates that the annual net trade balance has been consistently negative since 2001 .

The analysis in this paper is motivated by several factors. First, Ndou (2020) concluded that the net trade balance responds more to the income effects compared to the real effective exchange rate effects in the short run. In addition, the long-run and short-run effects of domestic income on the net trade balance were found to be much bigger than those induced by the real effective exchange rate. ${ }^{1}$ However, the separate influence of the price level and the nominal effective exchange rate on the South African trade balance are unknown. Hence, this analysis decomposes the real effective exchange rate into the nominal effective exchange rate, foreign and domestic price levels, to determine the separate effects of these components on the net trade balance. For instance, Junz and Rhomberg (1973) stated that the adjustment of trade flows to the exchange rate depreciation comprise of recognition lag, production lag, decision lag, delivery lags of payments and replacement lag. Junz and Rhomberg (1973) and Magee (1973) explained the short-run worsening and long-run improvement in trade balance following the exchange rate depreciations. ${ }^{2}$

The second motivation is that the South Africa government desperately needs to stimulate economic growth and the exchange rate is one of the important policy tools available to perform this task. For a long time, the manufacturing sector lobby groups have called for a weaker exchange rate when the Rand exchange rate to the US dollar was below R10/US\$ pre-2009 and the exchange rate has depreciated by nearly $80 \%$ to reach R19/US\$ in April 2020. This is one of the reasons why

\footnotetext{
${ }^{1}$ Methodologically, the real effective exchange rate comprises the nominal exchange effective rates and relative prices.

2 The effects of the currency devaluation in the US have been examined by various authors and indicate mixed results and different policy implications (Bahmani-Oskooee and Ratha 2004; Chiu et al. 2010).
} 
this paper examines the long-run and short-run effects of the exchange rate changes on net trade balance in South Africa and thereafter compares these effects to those induced by the domestic and foreign income; and the price level.

The third motivation is that the contribution of the net trade balance to GDP has been persistently very small over a long period of time. The policy discussions have pointed towards exports-led growth and the reduction of imports growth as a potential growth strategy. Hence, the analysis in this paper contributes to the discussions on the net trade balance by determining whether the South African net trade balance dynamics are primarily driven by the exchange rate effects or the income effects and the inflation targeting policy framework. The findings from this analysis have implications for the design of the exchange rate policy and industrial policy, as they affect the intervention strategies in the import-substitution industries. The import substitution should not discourage total imports of goods such as capital or manufactured components, but should reduce the percentage of imports, while encouraging firms to relocate some of their productions units domestically or via the promotion of domestic industries with intention to low their dependence on foreign trade.

The third motivation is due to theory, on the adjustment of the net trade balance, which is not explicit regarding the magnitudes of the short-run and long-run impacts of the exchange rate, domestic and foreign consumer price levels, domestic and foreign incomes on the net trade balances. Theory is not clear as to which amongst these factors has a big impact on the net trade balance and this aspect is still unknown and remains an empirical issue.

There are very few studies in South Africa that have focussed on the link between real effective exchange rate and trade balance. In addition, none of these studies have examined the disaggregated impact of the real effective exchange rate components on the South African trade balance. The first contribution of this paper is by filling gaps in Chiloane et al (2014), Schaling and Kabundi (2014) and Matlasedi et al (2015) who examined the effects of exchange rate on the trade balance in South Africa, but did not investigate the disaggregated effects of nominal effective exchange rate, domestic and foreign price on the net trade balance. This study contributes to the literature by determining the component of the real effective exchange rate that is a big driver of the South African net trade balance by disaggregating the real effective exchange rate into the nominal effective exchange rate and the domestic and foreign price levels.

The second contribution of the study, is by determining how the exchange rate effects compare to the relative price level effects, as the paper tests the short-run and long-run empirical relevance of the elasticity effects and absorption effects by incorporating the exchange rate, price levels and income in the model. The exchange rate and price level are important policy variables given the current floating exchange rate regime and the inflation targeting policy framework. The money supply is not a policy target indicator in South Africa, hence I do not examine its effects as predicted by the monetarist approach to the balance of payments approach.

Third, the study contributes to the analysis of the net trade balance dynamics by testing the stability of estimated coefficient using the Hansen stability test to show that the net trade balance equation is stable over time. Such testing has not been done by previous studies examining the trade balance equation, given the global 
recession and the subsequent periods of volatile economic conditions in South Africa post-2009.

Fourth, the study contributes to literature by applying a bounds testing approach, which allows for the simultaneous testing of the short-run and long run effects. This has not been applied in South Africa using the disaggregated components of the real effective exchange rate. Fifth, by focussing on the effects of the consumer price level, this study will determine the extent to which relative prices influence the net trade balance. Sixth, quantifying the short-run and long-run responsiveness of the net trade balance to the exchange rate changes is important, because when there is no stable long-run relationship, then depreciating the exchange rate does not seem to be a reasonable way to improve the country's competitiveness on a long-term basis.

The remainder of this paper is organised as follows, "Stylised facts" shows the stylised facts between net trade balance and its various determinants. "Theory" briefly discusses the relevant literature and various theories of the balance of payments from two different views, namely, the elasticity approach and absorption approach to balance of payments. "Methodology" presents the econometric methodology used in this paper, "Unit root tests" shows the unit root tests while "Empirical results" discusses the empirical results. "Conclusions and policy implications" provides the main conclusions and policy implications of the results in the paper.

\section{Stylised facts}

I show the relationship between (i) the net trade balance and the nominal effective exchange rate, (ii) the net trade balance and domestic income measured by GDP and (iii) the net trade balance and foreign income measured by G7 GDP. The G7 GDP data are sourced from the OECD database. The G7 consumer price level is average of individual consumer price level of G7 economies. I use the G7 consumer price level as proxy for the foreign price level. These data are sourced from the IMF database. The rest of the data are obtained from the SARB database.

As per theoretical expectations discussed above, the scatter plots in Fig. 2 show that the net trade balance is negatively related to the nominal effective exchange rate. This suggests that the exchange rate appreciation leads to the trade balance deficit. The positive relationship between the net trade balance and foreign income suggests that an increase in foreign income raises the demand for South African exports, thereby improving the net trade balance, ceteris paribus. The negative relationship between the net trade balance and the domestic income suggests that an increase in domestic income raises the demand for South African imports, thereby leading to the deterioration in the net trade balance, ceteris paribus.

In addition, Fig. 3a shows a positive relationship between the G7 consumer price levels and the net trade balances. This preliminary evidence is consistent with the theoretical predictions. However, Fig. 3d shows a positive relationship between the net trade balance and domestic consumer price levels and this is counterintuitive to theoretical predictions explained earlier. The R-squares in Figs. 2 and 3 are exceptionally low indicating that each variable individually explains very little variation in the net trade balance in South Africa. 

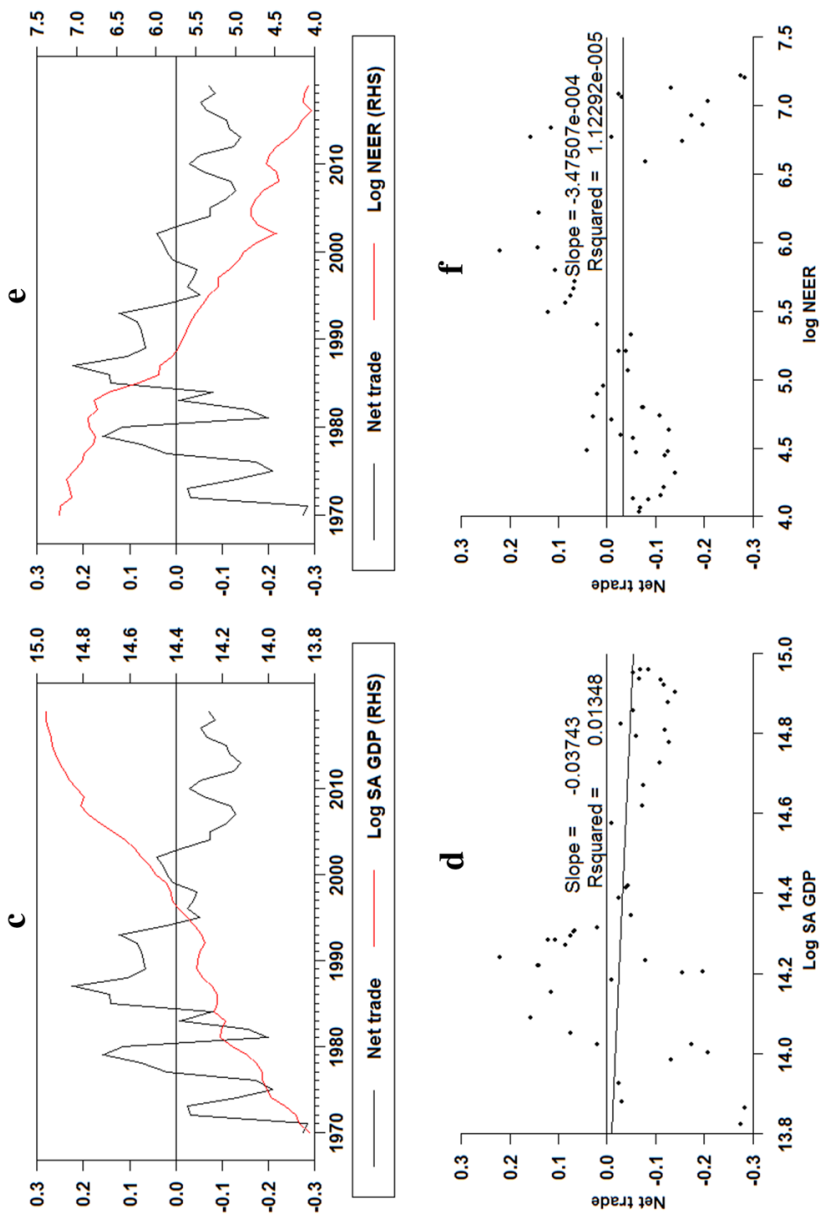

हี 

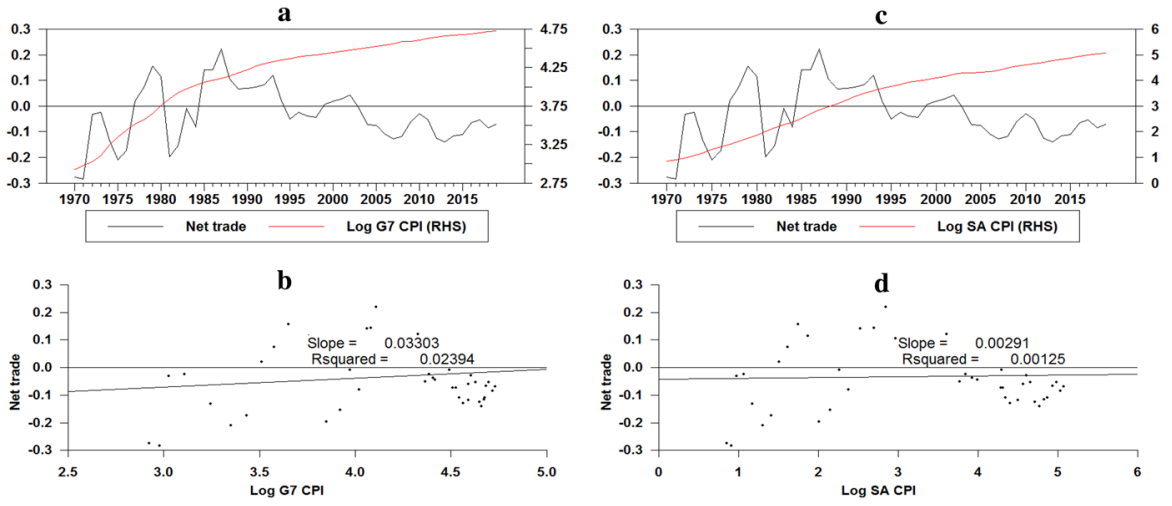

Fig. 3 Annual net trade balance, domestic consumer price level and the foreign price level

\section{Theory}

There are theories that explain the link between the exchange rate and the net trade balance. These are the elasticity approach and absorption approach to the balance of payments. The elasticity approach suggests that, starting from a balanced trade situation, the exchange rate depreciation will improve the balance of payments position only when the sum of the price elasticities of domestic and foreign demand for imports exceeds one. This happens via the substitution effects in consumption and production induced by the changes in the relative domestic and foreign prices which is induced by the exchange rate depreciation. By contrast, the absorption approach points out that the net trade balance will improve when the output effect of goods and services rises by more than its absorption effect. This absorption approach looks at the production and expenditure for the economy. The absorption effect refers to the expenditure by domestic residents on both goods and services. Thus, the currency depreciation will improve the trade balance only if the gap between domestic output and expenditure is widening. ${ }^{3}$

The models estimated in this analysis are based on the basic standard textbook econometric specification given by Eq. (1). This specification suggests that, domestic income, foreign income (or demand), foreign prices, domestic price and the nominal exchange rate are the main determinants of the net trade balance. In Eq. (1), $N T_{t}$ denotes the net trade balance which is given by the log of the ratio of total exports goods and services to total imports of goods and services. This specification follows Bahmani-Oskooee and Brooks (1999); Lal and Lowinger, (2001); and Onafowora (2003). The advantage of using the ratio for trade balance, is because, it is not

\footnotetext{
3 The monetarist approach, which is based on the demand and supply of the money, suggests that when money demand exceeds money supply, then the excess money demand is covered by the inflow of money from abroad, which improves the trade balance. Conversely, if money supply exceeds its demand, then excess money supply will flow out to other countries, thereby resulting in the deterioration in the trade balance.
} 
sensitive to the unit of measurement; hence, it can be interpreted as the nominal or real trade balance. $N E X H_{t}$ denotes the nominal effective exchange rate. $Y F_{t}$ denotes foreign income which captures foreign demand. Foreign demand is the combined GDP expenditures for $\mathrm{G} 7$ economies. $Y D_{t}$ denotes domestic income, $P F_{t}$ denotes the foreign price level which is the average consumer price level of G7 economies, while $P D_{t}$ denotes the domestic price level which is measured by the consumer price level.

$$
N T_{t}=f\left(N E X H_{t}, P F_{t}, P D_{t}, Y F_{t}, Y D_{t}\right)
$$

There are many specifications of Eq. (1) in empirical papers but the core specification used in this analysis is based on Eq. (2). Basic theory predicts that the coefficient $\beta_{N E X H}^{L R}$ is negative, which indicates that the exchange rate appreciation lowers the net trade balance. The coefficient $\beta_{Y F}^{L R}$ is predicted to be positive, suggesting that an increase in foreign income will raise demand for domestic exports. The coefficient $\beta_{Y D}^{L R}$ is expected to be negative, indicating that an increase in domestic income will lead to more demand for goods which will spill over to foreign demand which raises imports, and in turn leading to a deteriorating net trade balance. The coefficient $\beta_{P F}^{L R}$ is predicted to be positive, suggesting that an increase in foreign prices, is expected to make domestic goods less expensive and imports become expensive. This will raise demand for domestic exports which leads to improvement in trade balance. The coefficient $\beta_{P D}^{L R}$ is predicted to be negative, suggesting that an increase in domestic price, should make domestic goods expensive and imports become cheaper. This is expected to raise demand for foreign goods which leads to a deterioration in the trade balance. I use the log transformed variables in the estimation of the long-run impacts, hence the impacts can be interpreted as elasticities. If the impacts are bigger than one in magnitude, this implies more elasticity, while values between zero and one denote inelasticity, and values equal to one denote unit elasticity. The ect is the error term.

$$
N T_{t}=\alpha+\beta_{E X H}^{L R} \times N E X H_{t}+\beta_{P F}^{L R} \times P F_{t}+\beta_{P D}^{L R} \times P D_{t}+\beta_{Y F}^{L R} \times Y F_{t}+\beta_{Y D}^{L R} \times Y D_{t}+e c t_{t}
$$

\section{Methodology}

This paper applies an ARDL bounds testing technique introduced by Pesaran et al. (2001) to estimate the long-run and short-run effects of the exchange rate appreciation, domestic income and foreign income on the net trade balance. The advantages of using the ARDL over the Engle-Granger and Johansen tests, is that the latter two approaches require all variables to be non-stationary and the result of cointegration tests depend on the number of lags chosen and whether the trend is included in the test. Thus, when one changes, the number of lags will yield different results. The ARDL approach does not require all variables to be stationary and does not suffer from bias like the Johansen test. Ghatak and Siddiki (2001) suggest that the ARDL bound testing approach has more appropriate considerations than the Johansen-Juselius and Engle-Granger techniques for testing the cointegration 
among variables in small sample sizes. The ARDL approach can be used to examine the short-run and long-run dynamic interactions of the variables simultaneously and is robust for small samples (Bahmani-Oskooee and Nasir 2004; Lee 2010; Narayan, 2005; Cheng 2020; Hossain 2009). Furthermore, the ARDL application allows the variable to have different optimal lags, which is impossible with conventional cointegration procedures (Ozturk and Acaravci 2011). The ARDL technique cannot be applied to variables that are integrated of order 2 or I(2) and provides consistent and robust parameter estimates for both the short-run and long-run estimations.

\section{The ARDL model}

I start by estimating the error-correction form of the ARDL model given by Eq. (3). In the equations, $D_{i}$ is the dummy that equals to one in the indicated year or period and zero otherwise. ITDummy is dummy which equals to one beginning in 2000 to end of sample and zero otherwise. I have decomposed the real effective exchange rate into the nominal effective exchange rate, domestic price level and foreign price level.

$$
\begin{aligned}
\Delta N T= & \alpha_{1}+\vartheta \operatorname{Trend}+\sum_{i=0}^{n} \gamma_{i} \Delta L Y F_{t-i}+\sum_{i=0}^{n} \varphi_{i} \Delta L N E X H_{t-i} \\
& +\sum_{i=0}^{n} \omega_{i} \Delta L Y D_{t-i}+\sum_{i=0}^{n} \mu_{i} \Delta L P D_{t-i}+\sum_{i=0}^{n} \sigma_{i} \Delta L P F_{t-i} \\
& +\theta_{1} N T_{t-1}+\theta_{2} L Y F_{t-1}+\theta_{3} L N E X H_{t-1}+\theta_{4} L Y D_{t-1}+\theta_{5} L P D_{t-1}+\theta_{6} L P F_{t-1}+\beta_{i} I T D u m m y+\pi_{i} D_{i}+\varepsilon_{t}
\end{aligned}
$$

The short-run and long-run impacts are captured by different parameters in Eq. (3). The short-run impacts of the variables in the Eq. (3) are given by $\gamma_{i}, \varphi_{i}, \mu_{i}, \sigma_{i}$ and $\omega_{i}$. The $\theta_{1}, \theta_{2}, \theta_{3}, \theta_{4}, \theta_{5}$ and $\theta_{6}$ capture the long-run impacts. I estimate Eq. (3) using the general to specific approach by removing the insignificant lagged terms, choosing the model whose signs of impact are consistent with theoretical predictions and I show the stability tests as measured by the Hansen stability test on individual variables.

I start by estimating Eq. (3) using four lags and sequentially eliminate the insignificant lagged terms. I set the $\Delta N T=0, \Delta L Y F_{t-1}=0, \Delta L N E X H_{t-1}=0, \Delta L P D_{t-1}=0$, $\Delta L P F_{t-1}=0$ and $\Delta L Y D_{t-1}=0$, in Eq. (3) to derive the long-run elasticities of the exchange rate $E_{N T_{-} E X C H}$, domestic income, $E_{N T_{-} Y D}$, domestic price $E_{N T_{-} P D}$, foreign price $E_{N T_{-} F P}$ and foreign income $E_{N T_{-} Y F}$. The long run elasticities are derived using the following formula:

$$
E_{N T_{-} E X H}=\frac{\theta_{3}}{\theta_{1}}, E_{N T_{-} Y F}=\frac{\theta_{2}}{\theta_{1}}, E_{N T_{-} P D}=\frac{\theta_{5}}{\theta_{1}}, E_{N T_{-} P F}=\frac{\theta_{6}}{\theta_{1}} \text { and } E_{N T_{-} Y F}=\frac{\theta_{4}}{\theta_{1}}
$$

\section{The restricted version of the ARDL}

To test for the robustness of the findings using Eq. (3), I estimate a more restricted ARDL model given by Eq. (5) and test the significance of the error-correction terms $\delta$. The coefficient of the error term is expected to be negative and significant, which is indicative of correction towards equilibrium. 
Table 1 Augmented Dickey fuller critical unit root tests

\begin{tabular}{|c|c|c|c|c|}
\hline & \multicolumn{2}{|l|}{ Level } & \multicolumn{2}{|c|}{ Differenced } \\
\hline & Intercept & Intercept and trend & Intercept & Intercept and trend \\
\hline YF & -5.69 & -2.07 & -3.53 & -4.71 \\
\hline YD & -0.65 & -2.00 & -4.73 & -4.70 \\
\hline Net trade balance & -3.52 & -3.58 & -6.62 & -6.65 \\
\hline PD & 3.61 & 0.29 & -1.96 & -4.79 \\
\hline $\mathrm{PF}$ & -2.72 & -1.62 & -3.05 & -3.99 \\
\hline NEER & -3.44 & -0.90 & -5.34 & -5.20 \\
\hline
\end{tabular}

Augmented Dickey Fuller critical test values at $1 \%, 5 \%$ and $10 \%$ level of significance are -3.588509 , - 2.929734 and - 2.603064. Augmented Dickey Fuller critical test values for differenced data at $1 \%$, $5 \%$ and $10 \%$ levels of significance are $-4.180911,-3.515523$ and -3.188259 . Augmented Dickey Fuller critical test values intercept and trend at $1 \%, 5 \%$ and $10 \%$ level of significance are $-3,574,446 ;-$ 2,923,780 and - 2,599,925. Augmented Dickey Fuller critical test values for differenced data at $1 \%, 5 \%$ and $10 \%$ levels of significance are $-4,180,911,-3,515,523$ and $-3,188,259$

Table 2 Break point unit root test

\begin{tabular}{llllll}
\hline Variable & \multicolumn{2}{l}{$\begin{array}{l}\text { Break specification: inter- } \\
\text { cept only }\end{array}$} & & \multicolumn{2}{l}{$\begin{array}{l}\text { Break specification: } \\
\text { trend and intercept }\end{array}$} \\
\cline { 2 - 3 } \cline { 5 - 6 } & $T$ stat & $P$ value & & $T$ stat & $P$ value \\
\hline PD & -3.375 & 0.764 & & -3.489 & 0.818 \\
$\Delta \mathrm{PD}$ & -5.877 & 0.010 & & -5.492 & 0.021 \\
$\mathrm{PF}$ & -3.860 & 0.461 & & -4.203 & 0.392 \\
$\Delta \mathrm{PF}$ & -4.768 & 0.065 & -4.901 & 0.098 \\
\hline
\end{tabular}

$$
\begin{aligned}
\Delta N T_{t}= & \delta \varepsilon_{t-1}+\sum_{i=0}^{4} \varphi_{i} \Delta L Y F_{t-i}+\sum_{i=0}^{4} \omega_{i} \Delta L Y D_{t-i}+\sum_{i=0}^{4} \varphi_{i} \Delta L E X C H_{t-i} \\
& +\sum_{i=0}^{n} \mu_{i} \Delta L P D_{t-i}+\sum_{i=0}^{n} \sigma_{i} \Delta L P F_{t-i}+\varepsilon_{t}
\end{aligned}
$$

\section{Unit root tests}

Table 1 shows the unit roots test results based on the Augmented Dickey Fuller unit root test using annual data from 1970 to 2019. The null hypothesis is that each series is non-stationary (or the series has a unit root). Some of the results in Table 1 conclude that the variables are non-stationary at different significance levels and become stationary after differencing once.

I further examine the unit root tests for the consumer price level using the breakpoint test. The Augmented Dickey fuller $t$-statistics are shown in Table 2, and indicate that the consumer price level is stationary after differencing once even when 
Table 3 Results of the ARDL model

\begin{tabular}{|c|c|c|c|c|}
\hline \multirow[t]{2}{*}{ Variable } & \multicolumn{2}{|l|}{ Model 1} & \multicolumn{2}{|l|}{ Model 2} \\
\hline & Coefficient & $P$ value & Coefficient & $P$ value \\
\hline Constant & 6.795 & 0.08 & 8.005 & 0.05 \\
\hline Trend & 0.033 & 0.03 & 0.028 & 0.06 \\
\hline$\Delta \mathrm{LPF}_{t}$ & -1.079 & 0.23 & & \\
\hline$\Delta \mathrm{LYF}_{t}$ & 0.408 & 0.06 & 0.451 & 0.03 \\
\hline$\Delta \mathrm{LNEXCH}_{t}$ & -0.238 & 0.04 & -0.300 & 0.00 \\
\hline$\Delta \mathrm{LPD}_{t}$ & -0.859 & 0.09 & -1.174 & 0.02 \\
\hline$\Delta \mathrm{LYD}_{t}$ & -2.225 & 0.00 & -2.387 & 0.00 \\
\hline $\mathrm{LNT}_{t-1}$ & -0.648 & 0.00 & -0.649 & 0.00 \\
\hline $\mathrm{LPF}_{t-1}$ & 0.554 & 0.00 & 0.678 & 0.00 \\
\hline $\mathrm{LYF}_{t-1}$ & 0.324 & 0.04 & 0.241 & 0.09 \\
\hline $\mathrm{LNEXCH}_{t-1}$ & -0.340 & 0.00 & -0.381 & 0.00 \\
\hline $\mathrm{LPD}_{t-1}$ & -0.831 & 0.00 & -0.803 & 0.00 \\
\hline $\mathrm{LYD}_{t-1}$ & -0.999 & 0.01 & -0.939 & 0.02 \\
\hline D1999 & 0.133 & 0.00 & 0.121 & 0.00 \\
\hline D1994 & -0.091 & 0.00 & -0.100 & 0.00 \\
\hline ITDUM & 0.035 & 0.00 & 0.030 & 0.02 \\
\hline \multicolumn{5}{|l|}{ Model selection } \\
\hline Centred $R^{2}$ & 0.73 & & 0.72 & \\
\hline R-Bar^2 & 0.60 & & 0.60 & \\
\hline Akaike crit & -128.69 & & -128.23 & \\
\hline Schwarz crit & -98.75 & & -100.16 & \\
\hline Log Likelihood & 80.35 & & 79.12 & \\
\hline \multicolumn{5}{|l|}{ Testing existence of long-run relationship } \\
\hline $\begin{array}{l}\text { Hypothesis that } \\
\qquad \theta_{1}=\theta_{2}=\theta_{3}=\theta_{4}=\theta_{5}=\theta_{6}=0\end{array}$ & 7.44 & 0.00 & 7.60 & 0.00 \\
\hline Hypothesis that $\theta_{1}=0$ & -5.1 & 0.00 & -5.02 & 0.00 \\
\hline Decision & \multicolumn{4}{|c|}{ Yes, there is a long run relationship } \\
\hline
\end{tabular}

The dependent variable is DLNTt and (.) denotes the $t$-statistics

using the breakpoint tests. This enables me to do the econometric estimations as the methodology does not require the variables that are integrated order two I(2).

\section{Empirical results}

\section{The results on hypothesis testing}

I separate the discussion of the results from Eq. (3) into two main hypotheses. The first hypothesis determines if there is a long-run relationship. The second hypothesis determines the speed of adjustment towards equilibrium and is also a test of the 
Table 4 Long-run and short-run impacts

\begin{tabular}{|c|c|c|c|c|}
\hline \multirow[t]{2}{*}{ Variable } & \multicolumn{2}{|l|}{ Model 1} & \multicolumn{2}{|l|}{ Model 2} \\
\hline & Coefficient & $P$ value & Coefficient & $P$ value \\
\hline \multicolumn{5}{|c|}{ Short-run impacts } \\
\hline$\Delta \mathrm{LPF}_{t}$ & -1.079 & 0.23 & & \\
\hline$\Delta \mathrm{LYF}_{t}$ & 0.408 & 0.06 & 0.451 & 0.03 \\
\hline$\Delta \mathrm{LNEXCH}_{t}$ & -0.238 & 0.04 & -0.300 & 0.00 \\
\hline$\Delta \mathrm{LPD}_{t}$ & -0.859 & 0.09 & -1.174 & 0.02 \\
\hline$\Delta \mathrm{LYD}_{t}$ & -2.225 & 0.00 & -2.387 & 0.00 \\
\hline \multicolumn{5}{|c|}{ Long-run impacts } \\
\hline $\mathrm{LPF}_{t-1}$ & 0.855 & 0.00 & 1.045 & 0.00 \\
\hline $\mathrm{LYF}_{t-1}$ & 0.500 & 0.03 & 0.371 & 0.09 \\
\hline $\mathrm{LNEXCH}_{t-1}$ & -0.525 & 0.00 & -0.586 & 0.00 \\
\hline $\mathrm{LPD}_{t-1}$ & -1.282 & 0.00 & -1.237 & 0.00 \\
\hline $\mathrm{LYD}_{t-1}$ & -1.542 & 0.00 & -1.447 & 0.01 \\
\hline
\end{tabular}

(.) denotes the respective $t$-statistics

existence of a long-run relationship. The estimated results are shown in Tables 3 and 4.

I begin by testing the long-run equilibrium relationship hypothesis that $\theta_{1}=\theta_{2}=\theta_{3}=\theta_{4}=\theta_{5}=\theta_{6}=0$. I use the Wald test for the joint null hypothesis that all the coefficients of the variables in levels in Eq. (3) are equal to zero. The estimated $F$-statistics are compared with the bounds $F$-critical values to determine whether there exists a long-run relationship between the net trade balance, domestic income, domestic consumer price, foreign income, foreign consumer price and the exchange rate. I have estimated several models and applied the various model selection techniques. The final models are the selected models based on the expected theoretical signs. I use the critical values from Pesaran et al. (1996, 2001). Table 3 shows the bound test for the existence of a long-run equilibrium. The results which met the abovementioned criteria are from the models with both a constant and a trend. The $90 \%, 95 \%$ and $99 \%$ bounds $F$-critical test bands for $k=5$ are $\{2.75 ; 3.79\}$, $\{3.12 ; 4.25\}$ and $\{3.93 ; 5.23\}$ for the model with both a constant and a trend. The calculated $F$-statistics are 7.44 and 7.60 in Models 1 and 2, respectively. These exceed the bounds $F$-critical test band, which indicates the existence of a longrun relationship. This means that the null hypothesis of a no long-run relationship between the net trade balance, the domestic income, the foreign income, domestic consumer price level, foreign consumer price level and the exchange rate, is rejected. I therefore conclude that there is a long-run relationship.

I also test for the existence of a long-run relationship by looking at the speed of adjustment. The speed of adjustments in Eq. (3) is captured by $\theta_{1}$. The presence of the long-run relationship between the net trade balance, the domestic income, the foreign income, domestic consumer price level, foreign consumer price level and the exchange rate can be examined by testing the significance of the error-correction term in Eq. (3). This is done by testing the significance of the coefficient of $L N T_{t-1}$. 
Table 5 Model diagnostics

\begin{tabular}{|c|c|c|c|c|c|c|}
\hline \multirow[t]{2}{*}{ Variable } & \multicolumn{3}{|l|}{ Model 1} & \multicolumn{3}{|l|}{ Model 2} \\
\hline & Test statistics & & $P$ value & Test statistics & & $P$ value \\
\hline \multicolumn{7}{|c|}{ RESET test or misspecification test } \\
\hline LM (1) & 0.248 & 0.619 & & 0.004 & 0.952 & \\
\hline \multicolumn{7}{|c|}{ Normality test on residuals } \\
\hline Jarque-Bera & 0.058 & 0.970 & & 0.191 & 0.900 & \\
\hline \multicolumn{7}{|c|}{ Dickey fuller test on residuals } \\
\hline$T$-Statistic & $-8.05870^{* *}$ & & & $-7.24980 * *$ & & \\
\hline \multicolumn{7}{|c|}{ West-Cho Modified $Q$ Test } \\
\hline$Q(2)$ & 1.690 & 0.430 & & 0.960 & 0.619 & \\
\hline \multicolumn{7}{|l|}{ Test for ARCH } \\
\hline $\operatorname{Arch}(2)$ & 0.355 & 0.703 & & 0.004 & 0.996 & \\
\hline \multicolumn{7}{|c|}{ Hansen Stability test for parameter constancy } \\
\hline Constant & 0.03 & 0.97 & & 0.03 & 0.97 & \\
\hline Trend & 0.05 & 0.87 & & 0.05 & 0.87 & \\
\hline$\Delta \mathrm{LYF}_{t}$ & 0.05 & 0.90 & & 0.05 & 0.90 & \\
\hline$\Delta \mathrm{LNEXCH}_{t}$ & 0.06 & 0.82 & & 0.06 & 0.82 & \\
\hline$\Delta \mathrm{LPD}_{t}$ & 0.03 & 0.97 & & 0.03 & 0.97 & \\
\hline$\Delta \mathrm{LYP}_{t}$ & 0.06 & 0.78 & & 0.06 & 0.78 & \\
\hline $\mathrm{NT}_{t-1}$ & 0.02 & 1.00 & & 0.02 & 1.00 & \\
\hline $\mathrm{LPF}_{t-1}$ & 0.04 & 0.95 & & 0.04 & 0.95 & \\
\hline $\mathrm{LYF}_{t-1}$ & 0.03 & 0.96 & & 0.03 & 0.96 & \\
\hline $\mathrm{LNEXCH}_{t-1}$ & 0.03 & 0.98 & & 0.03 & 0.98 & \\
\hline $\mathrm{LPD}_{t-1}$ & 0.05 & 0.90 & & 0.05 & 0.90 & \\
\hline $\mathrm{LYD}_{t-1}$ & 0.03 & 0.96 & & 0.03 & 0.96 & \\
\hline
\end{tabular}

(.) denote $P$ values

I use the critical values from Pesaran et al. (1996, 2001). The lower and upper bound $t$-critical values for $k=5$ are $\{-3.13 ;-4.21\}$ and $\{-3.41 ;-4.52\}$ at the $90 \%$ and $95 \%$ for the models with both a constant and trend. The calculated $t$-statistics are 5.09667 and -5.02 for Models 1 and 2, respectively. As shown in Table 3, the $t$-test statistics exceed the upper bound of the $t$-critical band. Hence, the null hypothesis of a no long-run relationship between the net trade balance, domestic income, domestic consumer price, foreign income, foreign consumer price and the exchange rate is rejected. I therefore conclude that there is a long-run relationship. The values of $\mathrm{LN}_{t-1}$ which measure the speed of adjustment after disequilibrium are -0.648 and - 0.649 in Models 1 and 2, respectively. These magnitudes suggest that about $64.8 \%$ and $64.9 \%$ of the disequilibria in the Models in Table 3 are corrected in each year.

The estimated short-run coefficients and the diagnostics statistics are shown in Tables 4 and 5, respectively. The diagnostics test statistics indicate that the model is adequately estimated, and the parameters do not violate the parameter constancy assumptions. 
The effects of the variables on the net trade balance have the expected signs. The negative sign of the coefficient of the domestic income variable supports the Keynesian view that the increase in income also increases demand of foreign goods and services, thereby worsening the trade balance. The elasticities of domestic income are bigger in the short run than in the long run. In addition, the sign of the impact of foreign income on the net trade is positive as expected in both the short run and long run. The long-run elasticities for foreign income, ranges between 0.5 and 0.371 in Models 1 and 2. The short-run impact ranges between 0.408 and 0.451 in Model 1 and Model 2, respectively. In addition, the exchange rate has a negative and highly significant effect on the balance of trade. This suggests that the exchange rate appreciation leads to the deterioration in the net trade balance. The long-run elasticises for the exchange rate are -0.525 and -0.586 in Model 1 and Model 2 , respectively. The long-run elasticities are bigger than the short-run impacts of 0.238 and -0.3 in Model 1 and Model 2, respectively. Thus, in the long run, the $1 \%$ nominal effective exchange rate appreciation lowers the net trade balance by nearly $0.525 \%$ and $0.586 \%$ in Model 1 and Model 2, respectively.

\section{Exchange rate versus price level and domestic income effects}

I show the comparison of the effects of the domestic exchange rate, domestic price level and domestic income effects. To determine which domestic variables have a bigger impact on the net trade balance, I show the comparison of the short-run and long-run impacts of domestic income, price levels and the exchange rate. These results have implications for the design of the exchange rate policy, inflation management policy and industrial policies which emphasise the value of import-substituting industries. The short-run and long-run impacts are shown in Fig. 4a and b. The results show that the impact of domestic income on the net trade balance is the biggest followed by consumer prices and the nominal effective exchange rate has the least impact. The findings of this pattern are robust in the two estimated models. The long-run impact of the domestic income is nearly double that of the exchange rate. This shows that the domestic income has a bigger effect on the net trade balance changes than both the consumer price levels and the exchange rate. This implies that policymakers designing the exchange rate policy should also design the appropriate industrial policy interventions which emphasise the value of import-substituting industries to eliminate the net trade deterioration. The finding that the domestic price level has a bigger effect than the exchange rate implies that the design of the inflation targeting policy framework matters.

I also compare the long-run impacts of domestic and foreign consumer price levels and incomes in Fig. 4c and d. The domestic consumer price and income have bigger long-run impacts in absolute values than the foreign impacts on the net trade balance. 

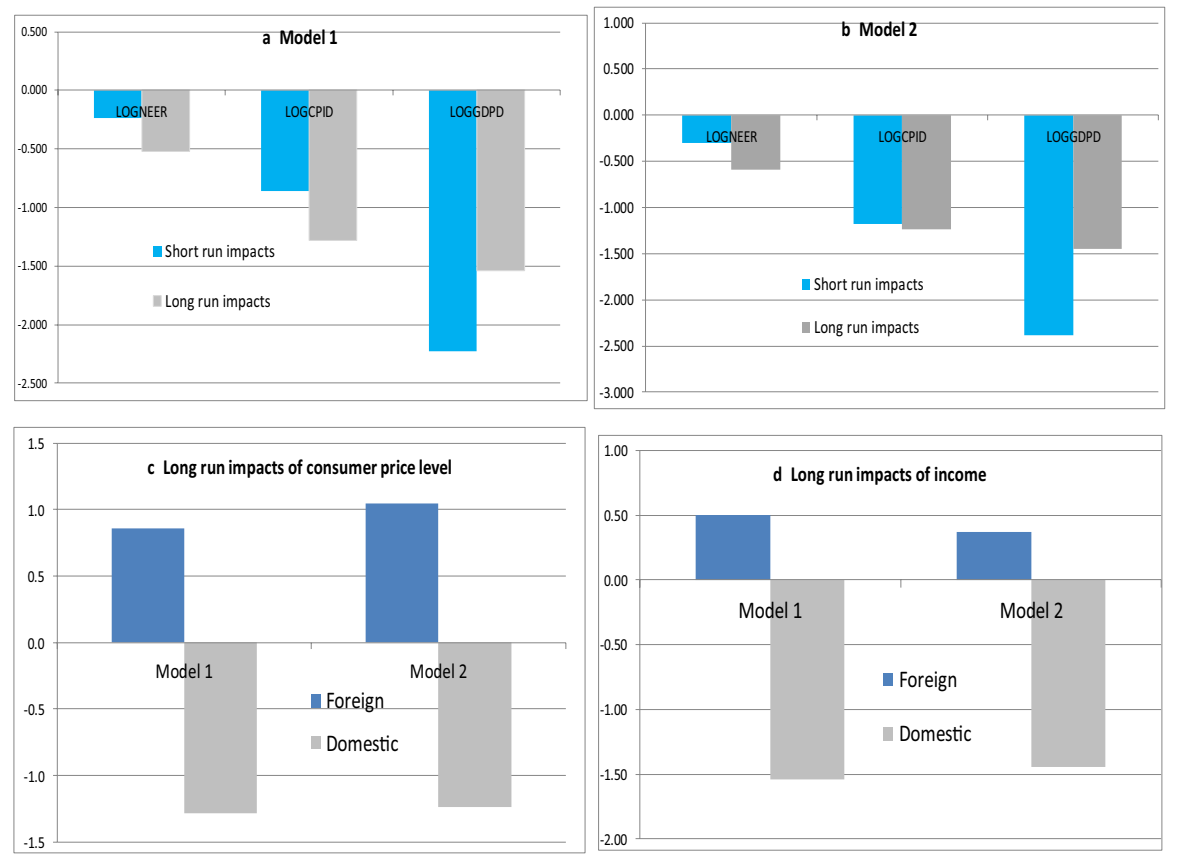

Fig. 4 Comparison of the impacts of domestic income, price level and the exchange rate

\section{The results from the restricted ARDL using Eq. (5)}

I estimate the short-run impacts and the speed of adjustment using Eq. (5). I determine the sign and the speed of the adjustment of the error term from the long-run equation to capture the correction or the speed of adjustment in Eq. (5). The finding of a significant speed of adjustment indicates the presence of a long-run relationship. Table 6 shows the long-run and short-run impacts estimated using Eqs. (5). The long-run impacts of foreign income, domestic income, domestic consumer price level, foreign price level and the exchange rate on the net trade balance are significant, and have the expected signs, which is consistent with theoretical predictions. The exchange rate appreciation significantly lowers the net trade balance. Both the foreign income and foreign consumer price levels significantly raise the net trade balance. The domestic income and domestic consumer price level have negative effects, which suggests that these lower the net trade balance.

The magnitude of domestic income dominates the effects of foreign income and the exchange rate impact in the short run. In fact, the impact of domestic income in the short run is nearly 10 times more than the size of the impact of the exchange rate on the net trade balance. The short-run impact of domestic income is nearly three times that of the foreign income. The estimated lagged error-correction term is negative and is statistically significant. This is additional evidence of the existence of the long-run relationship between the variables. The speeds of correction from disequilibrium suggest that 
Table 6 Results based on Eq. (5)

\begin{tabular}{|c|c|c|c|c|}
\hline \multirow{2}{*}{ Variable } & \multicolumn{2}{|l|}{ Model 1} & \multicolumn{2}{|l|}{ Model 2} \\
\hline & Coefficients & $P$ value & Coefficients & $P$ value \\
\hline \multicolumn{5}{|l|}{ Long-run impacts } \\
\hline Trend & 0.02 & 0.00 & & \\
\hline $\mathrm{LPF}_{t}$ & 0.53 & 0.00 & 0.59 & 0.00 \\
\hline $\mathrm{LYF}_{t}$ & 0.59 & 0.00 & 0.32 & 0.00 \\
\hline $\mathrm{LNEXCH}_{t}$ & -0.41 & 0.00 & -0.44 & 0.00 \\
\hline $\mathrm{LPD}_{t}$ & -0.91 & 0.00 & -0.66 & 0.00 \\
\hline $\mathrm{LYD}_{t}$ & -0.99 & 0.00 & -0.49 & 0.00 \\
\hline D99 & 0.07 & 0.00 & 0.11 & 0.00 \\
\hline D94 & -0.14 & 0.00 & -0.14 & 0.00 \\
\hline I TDUM & 0.02 & 0.06 & 0.01 & 0.62 \\
\hline \multicolumn{5}{|c|}{ Error correction model and short-run impacts } \\
\hline Constant & 0.07 & 0.02 & 0.07 & 0.03 \\
\hline ect $_{t-1}$ & -0.54 & 0.00 & -0.46 & 0.00 \\
\hline$\Delta \mathrm{LPF}_{t}$ & 0.18 & 0.72 & 0.34 & 0.51 \\
\hline$\Delta \mathrm{LYF}_{t}$ & 0.80 & 0.00 & 0.72 & 0.00 \\
\hline$\Delta \mathrm{LNEXCH}_{t}$ & -0.25 & 0.03 & -0.25 & 0.03 \\
\hline$\Delta \mathrm{LPD}_{t}$ & -0.95 & 0.03 & -0.95 & 0.04 \\
\hline$\Delta \mathrm{LYD}_{t}$ & -2.48 & 0.00 & -2.39 & 0.00 \\
\hline Centred & 0.56 & & 0.53 & \\
\hline Adjusted $R^{2}$ & 0.49 & & 0.47 & \\
\hline Akaike criterion & -122.76 & & -120.38 & \\
\hline Schwarz criterion & -109.66 & & -107.28 & \\
\hline
\end{tabular}

the system will adjust towards equilibrium by $54 \%$ and $46 \%$ annually in Model 1 and Model 2, respectively. In addition, the model diagnostics in Table 7 indicate the models are adequately estimated.

\section{Comparisons of the long-run and short-run effects of domestic variables namely: exchange rate, consumer price levels and incomes on net trade balance}

I show the comparison of the short-run and long-run impacts of domestic income, domestic consumer price level and the exchange rate on the net trade balance. The impacts are shown in Fig. 5. In the short run, the impact of domestic income is more than five times bigger than that of the exchange rate across all the models. The impact of domestic income is twice the impact of exchange rate. This shows that the domestic income has a bigger effect on the net trade balance than the consumer price level, and the exchange rate in the short run and the results are robust to different model specifications. 
Table 7 Model diagnostics

\begin{tabular}{|c|c|c|c|c|}
\hline \multirow[t]{2}{*}{ Variable } & \multicolumn{2}{|l|}{ Model 1} & \multicolumn{2}{|l|}{ Model 2} \\
\hline & Test statistic & $P$ value & Test statistic & $P$ value \\
\hline \multicolumn{5}{|l|}{ RESET test } \\
\hline $\mathrm{LM}(1)$ & 0.00 & 0.98 & 0.96 & \\
\hline \multicolumn{5}{|c|}{ Nomality test on residuals } \\
\hline Jarque-Bera & 0.13 & 0.94 & 0.47 & 0.79 \\
\hline \multicolumn{5}{|c|}{ Dickey Fuller unit root rest on residuals } \\
\hline$T$-Statistic & $-7.71 * *$ & & $? ? ? ?$ & \\
\hline \multicolumn{5}{|c|}{ West-Cho Modified Qstats } \\
\hline $\mathrm{Q}(2)$ & 2.17 & 0.34 & 0.32 & $? ? ? ?$ \\
\hline \multicolumn{5}{|l|}{$=$ McLeod-Li } \\
\hline McLeod-Li(2-0) & 1.82 & 0.40 & 3.97 & 0.14 \\
\hline \multicolumn{5}{|l|}{ Test for Arch effects } \\
\hline $\operatorname{Arch}(2)$ & 0.86 & 0.43 & 0.21 & $? ? ? ?$ \\
\hline \multicolumn{5}{|c|}{ Hansen stability tests } \\
\hline Constant & 0.099 & 0.57 & 0.096 & 0.59 \\
\hline ect $_{t-1}$ & 0.028 & 0.98 & 0.027 & 0.98 \\
\hline$\Delta \mathrm{LPF}_{t}$ & 0.041 & 0.93 & 0.040 & 0.93 \\
\hline$\Delta \mathrm{LYF}_{t}$ & 0.359 & 0.09 & 0.349 & 0.1 \\
\hline$\Delta \mathrm{LNEXCH}_{t}$ & 0.061 & 0.8 & 0.053 & 0.85 \\
\hline$\Delta \mathrm{LPD}_{t}$ & 0.054 & 0.85 & 0.052 & 0.86 \\
\hline$\Delta \mathrm{LYD}_{t}$ & 0.038 & 0.94 & 0.033 & 0.96 \\
\hline
\end{tabular}
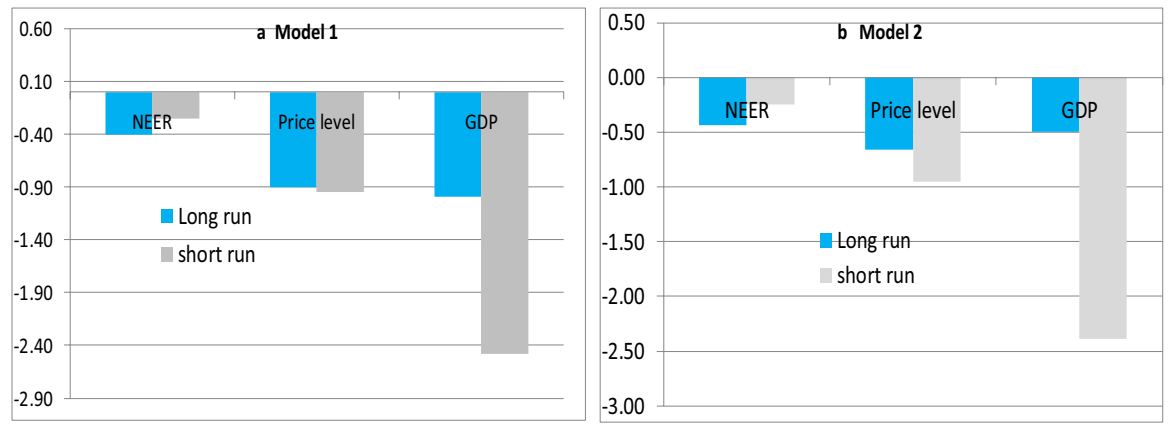

Fig. 5 The impacts of domestic income, consumer price level and exchange rate on the net trade balance

\section{Conclusions and policy implications}

This paper examined the long-run and short-run effects of the exchange rate changes on the net trade balance in South Africa and compared these effects to those induced by the foreign and domestic price levels and the domestic and foreign income effects. The paper applied the ARDL bounds testing approach and the restricted 
version of the ARDL bound testing approach. Using annual data from 1970 to 2019, it is found that the long-run elasticities of the exchange rate on the net trade balance are bigger than the short-run impacts. In both the short run and long run, the impact of domestic income on the net trade balance is the biggest followed by consumer price levels and the nominal effective exchange rate has the least impact. The long-run impact of domestic income is nearly twice larger than that of the exchange rate. This shows that domestic income has a bigger effect on the net trade balance than both the price levels and the exchange rate. These results imply that policymakers designing the exchange rate policy should also design the appropriate industrial policy interventions which emphasise the value of import-substituting industries to eliminate the net trade balance deterioration. At the same time, the design of the inflation targeting regime matters. Hence, there is therefore a need to pursue importsubstitution strategies to strengthen the domestic industrial base with all the associated multiplier effects throughout the economy. This industrial policy strategy also helps in reducing the worsening in trade deficits.

Funding There are no funding commitments and no conflict of interests in the production of this study.

Data availability The data that support the findings of this study are available from the corresponding author, upon a reasonable request.

\section{References}

Bahmani-Oskooee M, Brooks TJ (1999) Bilateral J-Curve between US and her trading partners. Weltwirtschaftliches Archiv 135:156-165

Bahmani-Oskooee M, Nasir ABM (2004) ARDL approach to test the poductivity bias hypothesis.Rev Dev Econ 8(3):483-488

Bahmani-Oskooee M, Ratha A (2004) The J-curve dynamics of US bilateral trade. J Econ Financ 28(1):32-38

Cheng KM (2020) Currency devaluation and trade balance: evidence from the US Service trade. J Pol Model 42:20-37

Chiloane L, Pretorius M, Botha I (2014) The relationship between the exchange rate and the trade balance in South Africa. J Econ Financ Sci 7(2):299-314

Chiu YB, Lee CC, Sun CH (2010) The US trade imbalance and real exchange rate: An application of the heterogenous panel cointegration method. Econ Model 27(3):705-716

Ghatak S, Siddiki J (2001) The use of ARDL approach in estimating virtual exchange rate in India. J Appl Stat 28:573-583

Hossain AA (2009) Structural change in the export demand functions for Indonesia: estimation, analysis and policy implications. J Pol Model 31:271-360

Junz HB, Rhomberg RR (1973) Price competitiveness in export trade among industrial countries. Am Econ Rev 63(2):412-418

Lal AK, Lowinger TC (2001) J-Curve: evidence from East Asia. Manuscript presented at the 40th Annual Meeting of the Western Regional Science Association, February 2001 in Palm Springs, CA.

Lee CG (2010) Health care and tourism: Evidence from Singapore. Tour Manag 31(4):486-488

Magee SP (1973) Currency contracts, pass-through and devaluation. Brook Pap Econ Act 193(1):303-325

Matlasedi T, Ilorah M, Zhanje S (2015) The impact of the real effective exchange rate on South Africa's Trade balance, Paper presented at the biennial conference of the Economic Society of South Africa, University of Cape Town, 2-4 September 2015

Narayan PK (2005) The savings and investment nexus for China: evidence from cointegration tests. Appl Econ 37(17):1979-1990 
Ndou E (2020) Exchange sensitivity and Trade balance in South Africa: Did global financial crisis impact the relationship? South African Reserve Bank Working paper (forthcoming)

Onafowora O (2003) Exchange rate and trade balance in East Asia: is there a J-Curve? Econom Bull 5(18):1-13

Ozturk I, Acaravc1 A (2011) Electricity consumption and real GDP causality nexus: evidence from ARDL bounds testing approach for 11 MENA countries. Appl Energy 88(8):2885-2892

Pesaran HM, Shin Y, Smith R (1996) Testing the existence of a long-run relationship. DAE Working Paper Series No. 9622, Department of Applied Economics, University of Cambridge.

Pesaran HM, Shin Y, Smith RJ (2001) Bounds testing approaches to the analysis of level relationships. J Appl Econom 16:289-326

Schaling E, Kabundi A (2014) The exchange rate, the trade balance and the J-Curve effect in South Africa. SAJEMS NS 17(5):601-608 